\title{
ZED
}

\section{ZED : The 'Zero Defect - Zero Effect' Initiative}

\begin{abstract}
FOREWORD
To support the 'Make in India' campaign, Ministry of Micro, Small and Medium Enterprise (MSME) has introduced the Zero Defect \& Zero Effect (ZED) scheme, where Quality Council of India (QCI) is the National Monitoring and Implementing Unit (NMIU). The Indian Institute of Welding (IIW-India) is associated with QCI for conducting the 'Industry Awareness Programme on Financial Support to MSMEs in ZED Certification Scheme'.

The ZED is the extensive drive of Government of India to enhance global competitiveness of MSMEs by providing them financial support in assessment, rating and handholding of its manufacturing process on Quality and Environment aspects. The complete details about the scheme is available at www.zed.org.in .
\end{abstract}

\section{THE ZED IN BRIEF}

This is a voluntary scheme and applicable to MSMEs for manufacturing sectors only. Presently, the scheme for service sector is under consideration by the ministry. A budget of ₹ 491 crores has been allocated for the total programme including the certification of 22, 222 MSMEs by March 2019.

ZED is a Maturity Assessment Model. The assessment of an enterprise will be on minimum 30 parameters out of 50 , including 20 mandatory parameters. There is an additional 25 parameters for the MSMEs supplying to defence sector. The maturity levels for each parameter is described here below:

The ZED rating is also comprises of 5 levels, which is the weightage average of total marks obtained through the parameters (minimum 30). The rating system is also described here:

\section{Each parameter comprises of 5 Maturity levels}

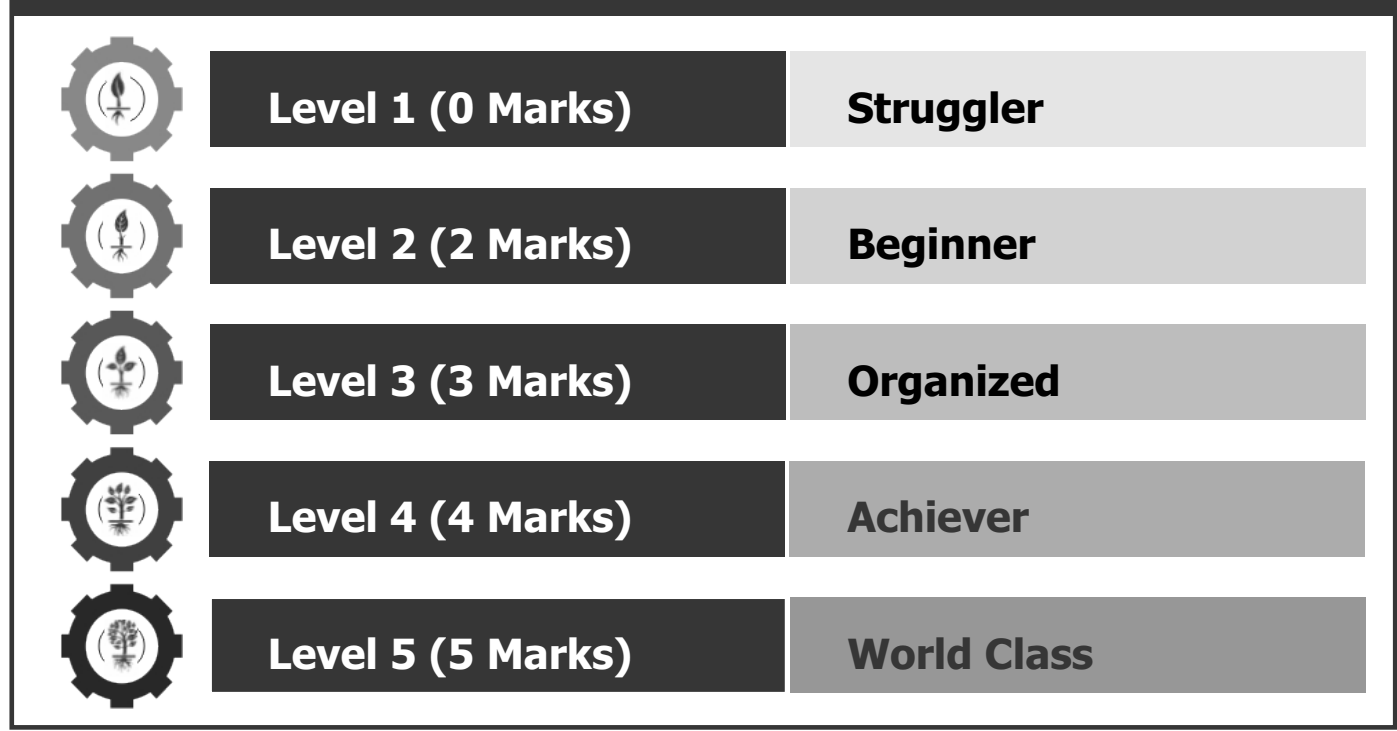




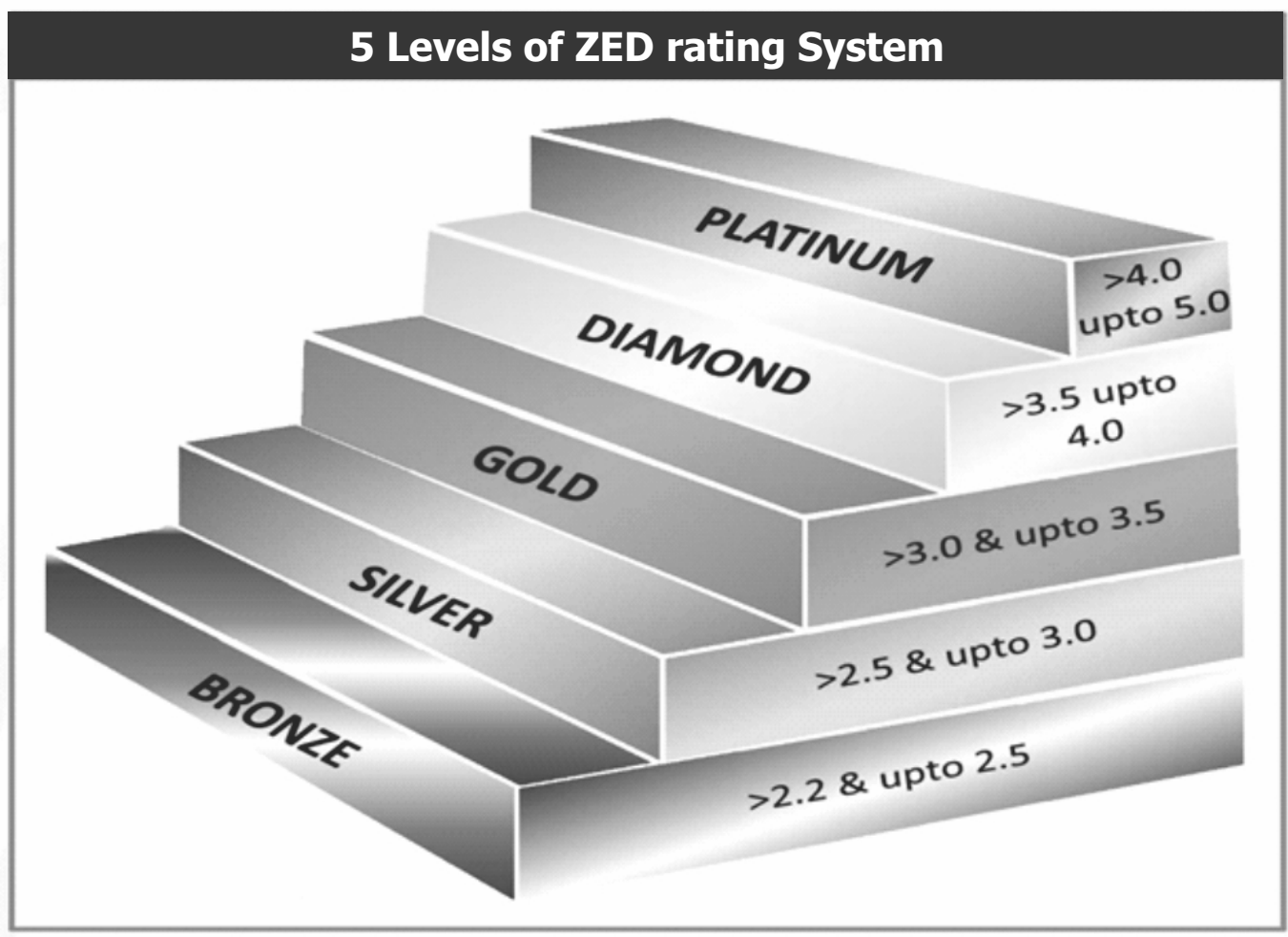

ZED is a $360^{\circ}$ coverage of an Enterprise from concept to customer satisfaction and it covers all the major interventions like ISO 9001 (QMS), ISO 14001 (EMS), Lean Manufacturing, 5S, Kaizen, Clean Development Mechanism, Supply Chain Management, Energy Conservation, Intellectual Property Rights, etc. And the major benefits of ZED Scheme for MSMEs are:

ZED is a $360^{\circ}$ coverage of an Enterprise from concept to customer satisfaction and it covers all the major interventions like ISO 9001 (QMS), ISO 14001 (EMS), Lean Manufacturing, 5S, Kaizen, Clean Development Mechanism, Supply Chain Management, Energy Conservation, Intellectual Property Rights, etc. And the major benefits of ZED Scheme for MSMEs are:

- Credible recognition for international investors seeking investment in India;

- Part of supply chain of national and international OEMs;

- Streamlined operations at lower costs;

- Superior quality, reduced rejection and higher revenues;

- Increased environmental consciousness and social benefits;

- "ZED MARK" to enable an MSME to be seen as a company with a difference.

\section{STEP PROCESS FLOW FOR ZED RATING:}

1. Registration: Online registration by MSMEs;

2. Online self-assessment: MSMEs to self-assess based on ZED parameters;

3. Desktop assessment: Assessment based on documents submitted by MSMEs;

4. Site assessment: On-site assessment of MSMEs qualified through desktop assessment;

5. ZED rating \& certification: Final rating and issuance of certificate (valid for 4 years);

6. Gap analysis \& handholding: Option to avail services of gap analysis \& handholding;

7. Re-assessment: Option to apply for re-assessment.

Also, there will be on-site surveillance, 2 times in a cycle.

Though the certification scheme is open for any size of organizations, the financial support by the Government will be provided only to the MSMEs. The financial support will be as follows:

To the Micro MSMEs: $80 \%$, to the Small MSMEs: $60 \%$, and to the Medium MSMEs: $50 \%$.

The certification cost as declared by the ministry: 


\begin{tabular}{|c|c|c|c|c|c|}
\hline & \multirow[b]{2}{*}{1} & Total Cost & \multicolumn{3}{|c|}{ Cost to MSMEs according to its Type } \\
\hline \multirow{3}{*}{$\begin{array}{c}\text { Desktop } \\
\text { Assessment } \\
\text { \& Site } \\
\text { Assessment }\end{array}$} & & $\begin{array}{l}\text { Registration \& Online } \\
\text { Self-assessment }\end{array}$ & $\begin{array}{l}\text { Micro } \\
\text { No Cost }\end{array}$ & $\begin{array}{l}\text { Small } \\
\text { No Cost }\end{array}$ & $\begin{array}{l}\text { Medium } \\
\text { No Cost }\end{array}$ \\
\hline & 2 & $\begin{array}{l}\text { Desktop Assessment } \\
\text { Rs. } 10,000 /-\end{array}$ & $\begin{array}{l}\text { Micro } \\
\text { Rs. 2000/- }\end{array}$ & $\begin{array}{l}\text { Small } \\
\text { Rs. 4000/- }\end{array}$ & $\begin{array}{l}\text { Medium } \\
\text { Rs. 5000/- }\end{array}$ \\
\hline & 3 & $\begin{array}{l}\text { Site Assessment } \\
\text { Rs. } \mathbf{8 0 , 0 0 0 / -}\end{array}$ & $\begin{array}{l}\text { Micro } \\
\text { Rs. } 16,000 /-\end{array}$ & $\begin{array}{l}\text { Small } \\
\text { Rs. 32000/- }\end{array}$ & $\begin{array}{l}\text { Medium } \\
\text { Rs. 40000/- }\end{array}$ \\
\hline \multicolumn{3}{|c|}{ TOTAL ASSESSMENT COST TO MSME } & Rs. 18000/- & Rs. 36000/- & Rs. 45000/- \\
\hline \multirow{3}{*}{$\begin{array}{l}\text { Assessment, } \\
\text { Consulting } \\
\& \text { Re- } \\
\text { Assessment }\end{array}$} & 4 & $\begin{array}{l}\text { Additional Defence } \\
\text { Rating } \\
\text { Rs. 40,000/- }\end{array}$ & $\begin{array}{l}\text { Micro } \\
\text { Rs. 8000/- }\end{array}$ & $\begin{array}{l}\text { Small } \\
\text { Rs.16000/- }\end{array}$ & $\begin{array}{l}\text { Medium } \\
\text { Rs.20000/- }\end{array}$ \\
\hline & 5 & $\begin{array}{l}\text { Gap analysis \& hand- } \\
\text { holding (optional) } \\
\text { Rs. 190,000/- }\end{array}$ & $\begin{array}{l}\text { Micro } \\
\text { Rs. } 38000 /-\end{array}$ & $\begin{array}{l}\text { Small } \\
\text { Rs.76000/- }\end{array}$ & $\begin{array}{l}\text { Medium } \\
\text { Rs.95000/- }\end{array}$ \\
\hline & 6 & $\begin{array}{l}\text { Re-assessment/ } \\
\text { Re-rating } \\
\text { Rs. 40,000/- }\end{array}$ & $\begin{array}{l}\text { Micro } \\
\text { Rs. 8000/- }\end{array}$ & $\begin{array}{l}\text { Small } \\
\text { Rs.16000/- }\end{array}$ & $\begin{array}{l}\text { Medium } \\
\text { Rs.20000/- }\end{array}$ \\
\hline
\end{tabular}

An additional subsidy of $5 \%$ will be provided to the MSMEs owned by SC/ST/Women and MSMEs located in North Eastern Region and Jammu \& Kashmir.

\section{IIW-INDIA \& ZED}

IIW-India has conducted a total of 17 Awareness Programmes in February (6 nos.) and March (11 nos.) 2017, with a cumulative turnout of 719 MSMEs. Out of these 17 programmes, 1 programme was conducted at Jamshedpur, 1 programme at Cochin and balance 15 programmes were conducted in different locations of West Bengal with the help from Event Management partner M/s. S. S. Technology.

The total programmes were coordinated by Mr. Rituraj Bose with the guidance from Mr. Parimal Biswas, Hony. Secretary
General and Mr. Pabitra Kumar Das, Past President. The Faculty for the ZED programmes were Mr. Rituraj Bose and Mr. Debajyoti Debnath; and well supported by the programme coordinators Ms. Mousumi De, Mr. Somenath Ghosh, Mr. Paramesh Krishna Dutta, Mr. Sandip Meta, Mr. Syriac Cherian, Mr. Arijoy Roy and Mr. Jose Philip.

IIW-India has decided to handhold with QCI for this noble cause of spreading the awareness of ZED certification scheme, which is India's own certification scheme and we all can be proud for the same.

\section{ACKNOWLEDGEMENT}

Literatures of Ministry of MSME and Quality Council of India.

Report by Rituraj Bose 